\title{
LITERATUR REVIEW: FAKTOR RISIKO ATTENTION DEFICIT HYPERACTIVITY DISORDER (ADHD)
}

\section{RISK FACTORS OF ATTENTION DEFICIT HYPERACTIVITY DISORDER (ADHD): LITERATURE REVIEW}

\author{
I. Made Sudarma Adiputra ${ }^{1}$, G. N. Indraguna Pinatih ${ }^{2}$, Ni Wayan Trisnadewi ${ }^{3}$, Ni Putu \\ Wiwik Oktviani ${ }^{4}$ \\ ${ }^{1}$ Program Studi S3 Ilmu Kedokteran, Universitas Udayana \\ ${ }^{2}$ Fakultas Kedokteran, Universitas Udayana \\ ${ }^{1,3,4}$ STIKES Wira Medika Bali
}

\begin{abstract}
ABSTRAK
Pendahuluan: Attention Deficit Hyperactivity Disorder (ADHD) adalah gangguan tumbuh kembang pada anak yang ditandai dengan gangguan aktivitas yang berlebih dan rendahnya perhatian anak usia prasekolah-sekolah. Anak yang menderita ADHD akan sangat sulit diatur dan cenderung mengalami masalah baik dirumah ataupun disekolah. studi literatur ini bertujuan untuk mendapatkan faktor risiko dari kejadian ADHD. Metode dan Hasil : Metode yang digunakan adalah literature review, pencarian artikel menggunakan beberapa sumber dari database : EBSCO HOST, Proquest, PubMed, Scient Direct dan Springer Link publikasi tahun 2010-2020, kata kunci yang digunakan "Risk Faktors", "adhd or attention deficit hyperactivity disorder, dengan menggunakan "AND" sebagai boolean operator. Terdapat sejumlah 309 artikel yang ditemukan sesuai dengan kata kunci tersebut. Setelah artikel tersebut dievaluasi sesuai kriteria yang diinginkan: full text, Bahasa yang digunakan dan kesesuaian rancangan didapatkan sejumlah 18 artikel yang ditelaah untuk di-review. Diskusi: Faktor risiko yang meningkatkan kejadian ADHD: Paparan asap rokok, Ibu merokok dan mengkonsumsi alkohol saat hamil, Ibu hamil yang obesitas, Riwayat kelahiran dengan berat badan lahir rendah (BBLR) dan kelahiran Prematur, APGAR skor rendah saat lahir, genetik dan lingkungan, social ekonomi orang tua, usia orang tua dan Riwayat kelahiran sectio caesaria (SC).
\end{abstract}

Kata Kunci: Literatur Review, Faktor Risiko, ADHD

\begin{abstract}
Introduction: Attention Deficit Hyperactivity Disorder (ADHD) is a growth and development disorder in children characterized by impaired excessive activity and
\end{abstract}


low attention of preschool-aged children. Children who suffer from ADHD will be very difficult to manage and tend to experience problems both at home or at school. This study literature aimed to obtain risk faktors for the incidence of ADHD. Methods and Results: The method used is literature review, search database using several sources from the database: EBSCO HOST, Proquest, PubMed, Scient Direct and Springer Link 2010-2020 publications, the keywords "Risk Faktors","'adhd or attention deficit hyperactivity disorder" Boolean operator "AND". There are total of 309 articles found in accordance with these keywords. The article was evaluated according to desirable criteria: full text, the language used and the suitability of the design, a total of 18 articles that are used for this review. Discussion: Risk faktors that increase the incidence of ADHD: Exposure to cigarette smoke, smoking and consuming alcohol during pregnancy, obese pregnant women, birth history with low birth weight (LBW) and premature birth, APGAR low score at birth, genetic and environmental conditions, socioeconomic parents, age of parents and birth history of sectio caesaria (SC).

Keywords: Literature Review, Risk Faktors, ADHD

\begin{tabular}{ll}
\hline Alamat Korespondensi & $:$ STIKES Wira Medika Bali \\
Email & $:$ dharma adiputra@yahoo.com \\
\hline
\end{tabular}

\section{PENDAHULUAN}

Attention Deficit Hyperactivity Disorder (ADHD) adalah gangguan tumbuh kembang pada anak yang ditandai dengan gangguan aktivitas yang berlebih dan rendahnya perhatian anak usia prasekolah-sekolah. Anak yang menderita ADHD akan sangat sulit diatur dan cenderung mengalami masalah baik dirumah ataupun di sekolah, tiga gejala pokok yang sering terlihat pada anak dengan ADHD: kesulitan dalam memusatkan perhatian, hiperaktivitas dan impulsivitas (Davison, Neale, \& Kring, 2010)

Prevalensi ADHD pada anak di dunia mencapai 3\%-7\% (Beaver, Nedelec, Rowland, \& Schwartz, 2012), sedangkan prevalensi ADHD di Amerika diperkirakan mencapai 11\% pada anak usia 4-17 tahun (Perera et al., 2018). Angka kejadian ADHD di menunjukkan angka yang bervariasi antara 2-20\%. Di Ukraina angka kejadian ADHD pada anak sekolah mencapai 20\%. Prevalensi ADHD belum diketahui secara pasti, penelitian yang dilakukan Muninggar (2011) menemukan prevalensi ADHD di Jakarta Pusat mencapai 4,2\% pada anak usia sekolah.

Penyebab ADHD pasti ADHD sampai saat ini belum diketahui pasti, akan tetapi ada beberapa faktor risiko yang diduga meningkatkan kejadian ADHD pada anak seperti faktor keturunan. Riwayat ibu merokok dan mengonsumsi minuman beralkohol saat hamil, terpapar asap rokok, Riwayat lahir prematur dan BBLR (Davison et al., 2010).

Dewasa ini terjadi kecendrungan peningkatan jumlah anak-anak yang mengalami ADHD, efek dari ADHD sangat dirasakan orang tua dan keluarga baik itu dari sisi medis, psikologis, sosial dan finansial (Adiputra, Trisnadewi, \& Parlin, 2018). Upaya komprehensif diperlukan untuk mencegah terjadinya ADHD, untuk 
itu diperlukan pengetahuan yang lebih baik terhadap faktor risiko yang memicu terjadinya ADHD dan ada beberapa faktor risiko lain yang diduga meningkatkan kejadian ADHD yang belum banyak dibuktikan sebelumnya. Dari studi literatur yang dilakukan, peneliti belum menemukan literatur review terkait faktor risiko kejadian ADHD.

Atas dasar fenomena tersebut maka literatur review ini dilakukan untuk suatu tujuan mengidentifikasi faktor risiko gangguan ADHD. Adapun tujuan studi literatur review adalah untuk mendapatkan faktor risiko dari kejadian ADHD. Hasil literatur review ini bisa digunakan sebagai masukan terkait penelitian faktor risiko kejadian ADHD di Indonesia.

\section{METODE PENELITIAN}

Metode yang digunakan dalam tulisan ini adalah literatur review. Pencarian artikel menggunakan beberapa sumber dari database EBSCO HOST, proquest, PubMed, Scient Direct dan Springer Link yang dipublikasikan dari tahun 2010 sampai dengan tahun 2020. Kata kunci dalam menemukan artikel, yaitu risk factors, ADHD or attention deficit hiperactivity disorder. Peneliti menggunakan "AND" sebagai boolean operator. Penggunaan boolean operator "AND" bertujuan untuk mengkombinasikan konsep dan aspek yang berbeda sebagai kata kunci pencarian sehingga mempersempit dokumen yang akan didapat. Terdapat sejumlah 309 artikel yang ditemukan sesuai dengan kata kunci tersebut. Setelah artikel tersebut dievaluasi sesuai kriteria: full text, jurnal akademik, rancangan (analitik) dan bahasa inggris, didapatkan sejumlah 18 artikel yang ditelaah untuk di-review. Teori lain juga digunakan dalam literatur review ini untuk memperkuat alasan dari literatur yang dikaji.

\section{HASIL DAN PEMBAHASAN}

\section{Hasil}

Dari hasil penelusuran jurnal didapatkan beberapa faktor risiko Attention Deficit Hyperactivity Disorder (ADHD) antara lain: Paparan asap rokok 2 artikel, Ibu merokok saat hamil 6 artikel, Riwayat ibu mengonsumsi alkohol saat hamil 2 artikel, Riwayat kelahiran dengan berat badan lahir rendah 2 artikel, Riwayat kelahiran Prematur 1 artikel, Riwayat APGAR skor rendah saat lahir 2 artikel, genetik 2 artikel, lingkungan 2 artikel, sosial ekonomi orang tua 2 artikel, tingkat Pendidikan orang tua 1 artikel, orang tua muda 1 artikel, Ibu obesitas 1 artikel, Ibu menderita gangguan kejiwaan 1 artikel, Riwayat kelahiran sectio caesaria (SC) 1 artikel.

Tabel Hasil Penelusuran

\begin{tabular}{|c|c|c|c|c|}
\hline Author & Title, Journal & Participants & Method & Result \\
\hline $\begin{array}{l}\text { (Perera et al., } \\
2018 \text { ) }\end{array}$ & $\begin{array}{l}\text { Combined effects of } \\
\text { prenatal exposure to } \\
\text { polycyclic aromatic } \\
\text { hydrocarbons and material } \\
\text { hardship on child ADHD } \\
\text { behavior problems. } \\
\text { Environmental Research }\end{array}$ & 351 & $\begin{array}{l}\text { prospective } \\
\text { cohort study }\end{array}$ & $\begin{array}{l}\text { Di antara } 351 \text { partisipan didapatkan hasil: anak-anak } \\
\text { dengan paparan PAH (polycyclic aromatic } \\
\text { hydrocarbons ) prenatal tinggi (adduksi tinggi) } \\
\text { umumnya memiliki lebih banyak gejala ADHD } \\
\text { (skor lebih tinggi) dibandingkan dengan mereka } \\
\text { yang memiliki PAH paparan rendah. Indeks ADHD } \\
(\mathrm{p}<0,008) \text {, DSM-IV lalai }(\mathrm{p}=0,006) \text {, DSM-IV } \\
\text { Masalah Impulsif Hiperaktif }(\mathrm{p}=0,033) \text {, dan Total } \\
\text { Indeks DSM-IV }(\mathrm{p}=0,009) \text {. }\end{array}$ \\
\hline
\end{tabular}


Bali Medika Jurnal.

Vol 8 No 1, 2021: 35-44

ISSN : 2615-7047

DOI: https://doi.org/10.36376/bmj.v8i1

\begin{tabular}{|c|c|c|c|}
\hline $\begin{array}{l}\text { (Abdel Hamed, } \\
\text { Hammad, } \\
\text { Salama, Yassa, } \\
\text { \& Awaga, 2019) }\end{array}$ & $\begin{array}{l}\text { Secondhand smoke as a risk } \\
\text { faktor for attention deficit } \\
\text { hyperactivity disorder in } \\
\text { children. Inhalation } \\
\text { Toxicology }\end{array}$ & $\begin{array}{l}70 \text { ADHD, } 30 \\
\text { Control }\end{array}$ & $\begin{array}{l}\text { Case-control } \\
\text { study }\end{array}$ \\
\hline $\begin{array}{l}\text { (Biederman, } \\
\text { Martelon, } \\
\text { Woodworth, } \\
\text { Spencer, \& } \\
\text { Faraone, 2017) }\end{array}$ & $\begin{array}{l}\text { Is Maternal Smoking During } \\
\text { Pregnancy a Risk Faktor for } \\
\text { Cigarette Smoking in } \\
\text { Offspring? A Longitudinal } \\
\text { Controlled Study of ADHD } \\
\text { Children Grown Up. } \\
\text { Journal of Attention } \\
\text { Disorders }\end{array}$ & $\begin{array}{l}96 \text { kasus, } 400 \\
\text { kontrol }\end{array}$ & $\begin{array}{l}\text { case--control } \\
\text { family studies }\end{array}$ \\
\hline
\end{tabular}

Hasil: Dari 70 anak ADHD, 62 (88,6\%) dari mereka melaporkan paparan asap rokok di rumah sementara dari 30 kontrol hanya hanya 14 anak $(46,7 \%)$ melaporkan paparan asap di rumah. Tingkat serum cotinine signifikan lebih tinggi pada kelompok ADHD daripada kelompok kontrol.

Hasil: terdapat hubungan yang signifikan diamati antara pajanan ibu yang merokok pada kehamilan terhadap anak yang dilahirkan $(p=0,02)$. Anak yang terpapar juga lebih cenderung memiliki tingkat depresi mayor yang lebih tinggi $(\mathrm{p}=0,04)$, gangguan bipolar $(\mathrm{p}=0,04)$, dan gangguan perilaku $(\mathrm{p}=0,04)$, dan IQ yang lebih rendah $(\mathrm{p}=0,01)$, lebih rendah Skor Global Assessment of Functioning (GAF) ( $\mathrm{p}=$ 0,02), dan skor Inventarisasi Penyesuaian Sosial untuk Anak dan Remaja (SAICA) yang lebih terganggu dibandingkan dengan anak yang tidak terpapar, disesuaikan dengan kelas sosial. Kesimpulan: Ibu Merokok selama kehamilan meningkatkan risiko ADHD dan berbagai gangguanl psikiatrik, kognitif, dan fungsional yang merugikan pada masa muda

$\begin{array}{lll}\text { (Istiklaili, } & \text { Risk factors affecting } & \text { Cross-Sectional } \\ \text { Suwandono, } & \text { attention deficit } & \\ \text { Suhartono, } & \text { hyperactivity disorder } & \\ \text { Widyorini, \& } & \text { among early childhood in } \\ \text { Saputro, 2019) } & \text { the agricultural area in } \\ & \text { Indonesia. Indian Journal of } \\ & \text { Public Health Research and } \\ & \text { Development }\end{array}$

Hasil penelitian menunjukkan bahwa dari 1.113 total subjek $480(43,1 \%)$ subjek dengan diagnose ADHD. Riwayat kelahiran prematur $(\mathrm{OR}=1.577 ; 95 \% \mathrm{CI}=$ 1.128-2.205), tingkat pendidikan ayah yang rendah $(\mathrm{OR}=1.422 ; 95 \% \mathrm{CI}=1.106-1.827)$, tingkat pendidikan ibu rendah $(\mathrm{OR}=1.312 ; 95 \% \mathrm{CI}=$ 1.008-1.708), orang tua bekerja sebagai petani (OR $=1.580 ; 95 \% \mathrm{CI}=1.231-2.028)$ dan gender $(\mathrm{OR}=$ $3.126 ; 95 \% \mathrm{CI}=2.4424 .001)$ terbukti menjadi faktor risiko independen untuk ADHD.

\begin{tabular}{|c|c|c|c|c|}
\hline $\begin{array}{l}\text { (Beaver et al., } \\
\text { 2012) }\end{array}$ & $\begin{array}{l}\text { Genetic risks and ADHD } \\
\text { symptomatology: Exploring } \\
\text { the effects of parental } \\
\text { antisocial behaviors in an } \\
\text { adoption-based study. Child } \\
\text { Psychiatry and Human } \\
\text { Development }\end{array}$ & 90.000 & $\begin{array}{l}\text { Prospective } \\
\text { Longitudinal } \\
\text { Study }\end{array}$ & $\begin{array}{l}\text { Hasil analisis dari sampe yang diambil dari National } \\
\text { Longitudinal Study of Adolescent } \\
\text { Health (Add Health) didapatkan bahwa gejala } \\
\text { ADHD meningkat pada anak yang memiliki orang } \\
\text { tua (Ibu dan Ayah kandung) pecandu alcohol. }\end{array}$ \\
\hline $\begin{array}{l}\text { (Noordermeer et } \\
\text { al., 2017) }\end{array}$ & $\begin{array}{l}\text { Risk faktors for comorbid } \\
\text { oppositional defiant disorder } \\
\text { in attention- } \\
\text { deficit/hyperactivity } \\
\text { disorder. European Child } \\
\text { and Adolescent Psychiatry }\end{array}$ & 246 & Case Control & $\begin{array}{l}\text { Ibu merokok selama kehamilan bertindak sebagai } \\
\text { faktor risiko minor untuk ADHD, sementara berat } \\
\text { badan lahir yang lebih tinggi bertindak sebagai } \\
\text { faktor risiko minor untuk ADHD + ODD }\end{array}$ \\
\hline $\begin{array}{l}\text { (Schwenke et al., } \\
2018 \text { ) }\end{array}$ & $\begin{array}{l}\text { Predicting attention deficit } \\
\text { hyperactivity disorder using } \\
\text { pregnancy and birth } \\
\text { characteristics. Archives of } \\
\text { Gynecology and Obstetrics }\end{array}$ & 573 & Cohorts Study & $\begin{array}{l}\text { Hasil penelitian ini didapatkan Ibu yang merokok } \\
\text { selama kehamilan dan anak yang lahir dengan Apgar } \\
\text { score kurang dari tujuh dalam satu menit kelahiran } \\
\text { mempunyai hubungan yang sangat signifikan } \\
\text { dengan kejadian ADHD di kemudian hari. }\end{array}$ \\
\hline $\begin{array}{l}\text { (Hanć et al., } \\
\text { 2018) }\end{array}$ & $\begin{array}{l}\text { Perinatal Risk Faktors and } \\
\text { ADHD in Children and } \\
\text { Adolescents: A Hierarchical } \\
\text { Structure of Disorder } \\
\text { Predictors. Journal of } \\
\text { Attention Disorders }\end{array}$ & $\begin{array}{l}132 \text { kasus, } \\
146 \text { kontrol }\end{array}$ & Case Control & $\begin{array}{l}\text { Data } 132 \text { anak laki-laki yang didiagnosis ADHD dan } \\
146 \text { anak laki-laki dari kelompok kontrol, berusia } 6 \\
\text { hingga } 18 \text { tahun, telah dianalisis. Anak-anak } \\
\text { dikategorikan menurut jangka waktu kelahiran, berat } \\
\text { lahir, dan skor Apgar. Metode CART (Klasifikasi } \\
\text { dan Pohon Regresi) digunakan untuk penilaian } \\
\text { hubungan antara faktor perinatal dan risiko ADHD. } \\
\text { Hasil: Skor Apgar Rendah ( } 21,97 \% \text { vs } 13,01 \% \text { ) dan } \\
\text { kelahiran post-term ( } 12,12 \% \text { vs } 0,68 \%) \text { lebih sering } \\
\text { pada sampel dibandingkan pada kelompok kontrol. } \\
\text { Metode CART juga menunjukkan berat badan lahir } \\
\text { rendah terkait dengan risiko ADHD. Di antara } \\
\text { faktor-faktor risiko yang dianalisis, skor Apgar } \\
\text { merupakan faktor risiko paling dominan terhadap }\end{array}$ \\
\hline
\end{tabular}


Bali Medika Jurnal.

Vol 8 No 1, 2021: 35-44

ISSN : 2615-7047

DOI: https://doi.org/10.36376/bmj.v8i1

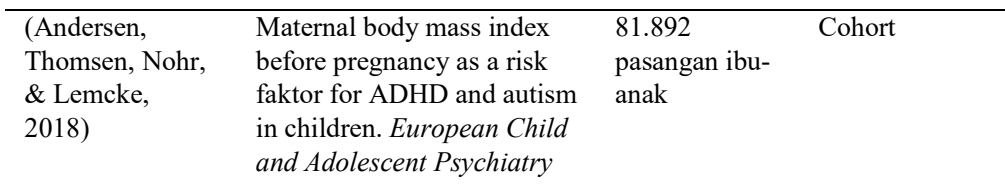

kejadian ADHD. Kesimpulan: Penurunan skor Apgar adalah faktor risiko perinatal ADHD yang paling penting.

Anak-anak dengan diagnosis klinis ADHD dan ASD diidentifikasi dalam daftar kesehatan Denmark pada usia rata-rata 13,3 tahun. Hazard Ratio (HR) diperkirakan menggunakan analisis waktu-keperistiwa. Dibandingkan dengan ibu dengan berat badan normal, risiko memiliki anak dengan ADHD meningkat secara signifikan jika ibu kelebihan berat badan $(\mathrm{HR}=1,28$ [95\% CI 1,15; 1,48]), obesitas $(\mathrm{HR}=1,47[95 \% \mathrm{CI} 1,26 ; 1,71]])$ atau sangat gemuk $(\mathrm{HR}=1,95[95 \%$ CI 1,$58 ; 2,40])$. Pola yang sama terlihat untuk kelompok ADHD dan ASD gabungan. Mengenai ASD, peningkatan risiko diamati pada ibu dengan berat badan kurang $(\mathrm{HR}=1,30[95 \% \mathrm{CI}$ $1,01 ; 1,69])$ dan obesitas ( $\mathrm{HR}=1,39$ [95\% CI 1,11; $1,75]$ ). Jadi dapat disimpulkan ibu yang obesitas lebih berisiko mempunyai anak ADHD.

\begin{tabular}{|c|c|c|c|c|}
\hline $\begin{array}{l}\text { (Hegelund, } \\
\text { Flensborg- } \\
\text { Madsen, } \\
\text { Vassard, } \\
\text { Niclasen, \& } \\
\text { Mortensen, } \\
\text { 2019) }\end{array}$ & $\begin{array}{l}\text { Parental socioeconomic } \\
\text { position and risk of ADHD } \\
\text { in offspring: a cohort study } \\
\text { of } 9648 \text { individuals in } \\
\text { Denmark 1976-2013. } \\
\text { European Child and } \\
\text { Adolescent Psychiatry }\end{array}$ & 9648 & $\begin{array}{l}\text { prospective } \\
\text { cohort study }\end{array}$ & $\begin{array}{l}\text { Hasil penelitian menunjukkan bahwa posisi social } \\
\text { ekonomi(SEP) orang tua yang rendah dikaitkan } \\
\text { dengan risiko lebih tinggi mempunyai anak ADHD. } \\
\text { Dengan demikian, keturunan orang tua dengan SEP } \\
\text { rendah memiliki } 4,52 \text { ( } 95 \% \text { CI } 2,81-7,26) \text { kali lebih } \\
\text { tinggi risiko memiliki anak dengan diagnosis ADHD } \\
\text { dibandingkan dengan orang tua dengan SEP tinggi. }\end{array}$ \\
\hline $\begin{array}{l}\text { (Chudal et al., } \\
\text { 2015) }\end{array}$ & $\begin{array}{l}\text { Parental age and the risk of } \\
\text { attention- } \\
\text { deficit/hyperactivity } \\
\text { disorder: A nationwide, } \\
\text { population-based cohort } \\
\text { study. Journal of the } \\
\text { American Academy of Child } \\
\text { and Adolescent Psychiatry }\end{array}$ & $\begin{array}{l}\text { 10,409 kasus } \\
\text { ADHD, } \\
39,125 \text { kontrol }\end{array}$ & $\begin{array}{l}\text { nested case- } \\
\text { control study }\end{array}$ & $\begin{array}{l}\text { Hasil penelitian: ayah yang berusia dibawah } 20 \\
\text { tahun memiliki } 1,5 \text { kali lipat (OR:1,55, 95\% CI: } \\
1,11-2,18 \text {, p:0,01) meningkatkan risiko memiliki } \\
\text { keturunan dengan ADHD dibandingkan dengan } \\
\text { ayah yang berusia } 25 \text { hingga } 29 \text { tahun. Ibu dari } \\
\text { kelompok usia yang sama memiliki } 1,4 \text { kali lipat } \\
\text { (OR: } 1,41 \text {, } 95 \% \text { CI: } 1,15-1,72, \quad \text { p:0,0009) } \\
\text { peningkatan risiko. }\end{array}$ \\
\hline $\begin{array}{l}\text { (Tuvblad, Zheng, } \\
\text { Raine, \& Baker, } \\
\text { 2009) }\end{array}$ & $\begin{array}{l}\text { A common genetic faktor } \\
\text { explains the covariation } \\
\text { among ADHD ODD and } \\
\text { CD symptoms in 9-10 year } \\
\text { old boys and girls. Journal } \\
\text { of Abnormal Child } \\
\text { Psychology }\end{array}$ & 1.219 & $\begin{array}{l}\text { Prospective } \\
\text { Longitudinal } \\
\text { Study }\end{array}$ & $\begin{array}{l}\text { Beberapa penelitian telah menemukan hubungan } \\
\text { antara genetic dengan malah ADHD, ODD dan CD. } \\
\text { Hasil penelitian ini ada hubungan atau pengaruh } \\
\text { faktor genetic dan lingkungan Bersama-sama } \\
\text { dengan kejadian ADHD, ODD dan CD. }\end{array}$ \\
\hline $\begin{array}{l}\text { (Septier et al., } \\
\text { 2019) }\end{array}$ & $\begin{array}{l}\text { Increased risk of ADHD in } \\
\text { families with ASD. } \\
\text { European Child and } \\
\text { Adolescent Psychiatry }\end{array}$ & 1.245 & $\begin{array}{l}\text { case-control } \\
\text { study }\end{array}$ & $\begin{array}{l}\text { Hasil dari penelitian ini ADHD lebih sering pada } \\
\text { kerabat }(19 \%) \text { daripada pada kelompok kontrol }(7 \%) \\
(\mathrm{p}=0,001) \text {. Risiko ADHD lebih tinggi pada } \\
\text { kelompok kerabat ASD+ daripada pada kelompok } \\
\text { kerabat ASD- (model GEE ATAU 1,58 [95\% CI } \\
1,04-2,38], \mathrm{p}=0,032) \text {. }\end{array}$ \\
\hline $\begin{array}{l}\text { (Chen et al., } \\
\text { 2014) }\end{array}$ & $\begin{array}{l}\text { Is atopy in early childhood a } \\
\text { risk faktor for ADHD and } \\
\text { ASD? A longitudinal study. } \\
\text { Journal of Psychosomatic } \\
\text { Research }\end{array}$ & $\begin{array}{l}14.812 \text { subyek } \\
\text { dgn penyakit } \\
\text { atopik (asma, } \\
\text { dermatitis } \\
\text { atopik, rinitis } \\
\text { alergi, atau } \\
\text { konjungtivitis } \\
\text { alergi) } \\
6944 \text { subjek } \\
\text { non-atopik }\end{array}$ & Cohort & $\begin{array}{l}\text { Hasil: Anak yang menderita penyakit atopik pada } \\
\text { anak usia dini meningkatkan risiko terjadinya } \\
\text { ADHD (hazard ratio [HR]: } 1.97 \text { ) dan ASD (HR: } \\
\text { 3.40) di kemudian hari. Jumlah komorbiditas atopik } \\
\text { yang lebih besar (4 komorbiditas: ADHD: HR: } 2.53 \text {; } \\
\text { ASD: HR: 4.29) signifikan, hal ini berkaitan dengan } \\
\text { risiko lebih besar mengalami ADHD dan ASD. } \\
\text { Diskusi: Diatesis atopik pada anak usia dini } \\
\text { meningkatkan risiko terjadinya ADHD dan ASD di } \\
\text { kemudian hari. }\end{array}$ \\
\hline $\begin{array}{l}\text { (Lehti, Chudal, } \\
\text { Suominen, } \\
\text { Gissler, \& } \\
\text { Sourander, 2016) }\end{array}$ & $\begin{array}{l}\text { Association between } \\
\text { immigrant background and } \\
\text { ADHD: a nationwide } \\
\text { population-based case-- } \\
\text { control study. Journal of } \\
\text { Child Psychology and }\end{array}$ & $\begin{array}{l}10.409 \text { kasus } \\
39.124 \text { kontrol }\end{array}$ & $\begin{array}{l}\text { case-control } \\
\text { study }\end{array}$ & $\begin{array}{l}\text { Hasil: kemungkinan diagnosis ADHD secara } \\
\text { signifikan meningkat di antara anak-anak dari dua } \\
\text { orang tua imigran [adjusted odds ratio (aOR) } 4,7 \text {, } \\
95 \% \text { CI } 3,4-6,6 \text { ] dan anak-anak dari ayah imigran } \\
\text { (aOR 1,9,95\% CI 1,6-2,2). Hubungan antara migrasi } \\
\text { orang tua dan diagnosis ADHD sangat kuat di antara } \\
\text { ayah yang lahir di Afrika sub-Sahara atau Amerika }\end{array}$ \\
\hline
\end{tabular}


Bali Medika Jurnal.

Vol 8 No 1, 2021: 35-44

ISSN : 2615-7047

DOI: https://doi.org/10.36376/bmj.v8i1

Psychiatry and Allied

Disciplines

Latin dan di antara para ibu yang lahir di Afrika subSahara atau Afrika Utara dan Timur Tengah. Anakanak, yang orang tuanya lahir di negara-negara dengan Indeks Pembangunan Manusia (HDI) yang rendah, lebih sering mengalami gangguan ADHD.

Kesimpulan: Meningkatnya kemungkinan diagnosis ADHD di kalangan anak-anak imigran menunjukkan peningkatan paparan terhadap lingkungan faktor risiko, perbedaan dalam penggunaan layanan kesehatan, atau tantangan dalam mendiagnosis anak-anak imigran

\begin{tabular}{llll}
\hline (Wang, Hu, & $\begin{array}{l}\text { Prenatal Tobacco Exposure } \\
\text { Chen, Xue, \& }\end{array}$ & $\begin{array}{l}\text { 168 pasien } \\
\text { Mudulated the Association } \\
\text { of Genetic variants with }\end{array}$ & $\begin{array}{l}\text { case-control } \\
\text { study }\end{array}$ \\
& $\begin{array}{l}\text { Diagnosed ADHD and its } \\
\text { symptom domain in }\end{array}$ & \\
children: A Community & & \\
& Based Case-Control Study. \\
& Scientific Reports
\end{tabular}

Paparan asap tembakau prenatal merupakan faktor risiko signifikan ADHD bahkan setelah disesuaikan untuk perancu potensial lainnya. ADRA2A rs553668, DRD2 rs1124491 dan SLC6A4 rs6354 diidentifikasi untuk dikaitkan dengan ADHD. Interaksi multiplikatif dan aditif gen-lingkungan yang signifikan diamati antara pse dan ADRA2A rs553668 dalam kaitannya dengan ADHD dan ADHD-ODD. Risiko varian genetik pada ADHD meningkat secara signifikan jika anak memiliki paparan tembakau prenatal. Risiko genetik untuk ADHD dapat dipengaruhi oleh adanya risiko lingkungan. risiko lingkungan dan genetik tidak berbeda satu sama lain. Lebih banyak studi interaksi lingkungan gen diperlukan untuk mengungkap etiologi ADHD.

\begin{tabular}{llll}
\hline (Saadi, & Socio-maternal risk faktors & 130 kasus & case-control \\
Shamsuddin, & of ADHD among Iraqi & 130 kontrol & study \\
Sutan, \& & children: A case-control & & \\
Alshaham, 2013) & $\begin{array}{l}\text { study. Open Journal of } \\
\text { Preventive Medicine }\end{array}$ & & \\
& &
\end{tabular}
Hasil: Lima variabel secara signifikan terkait risiko ADHD pada anak setelah menggunakan model multivariat regresi logistik, stres ibu saat hamil(Adjusted OR 9.08, 95\% CI 4.70 - 17,52 dan nilai $\mathrm{P}<0,001$ ), ibu merokok saat hamil(Adjusted OR 3,27 95\% CI 1,40 - 7,63, P <0,001), ayah kehilangan pekerjaan (Adjusted OR 2,81, 95\% CI $1,51-5,24$, nilai $\mathrm{P}<0,001)$, dan kekacauan rumah tangga (Adjusted OR 2,55, 95\% CI 1,04 - 6,24, P $<0,05$ ). Pendapatan keluarga juga dikaitkan dengan risiko ADHD (OR 1,02 95\% CI 1,00-3,12, nilai P $<0,05)$.

\begin{tabular}{lllll}
\hline (Amiri, Malek, & Pregnancy-Related Maternal & 164 children & case-control & Hasil dari penelitian ini didapatkan empat variabel \\
Sadegfard, \& & Risk Faktors of Attention- & with ADHD & study & $\begin{array}{l}\text { yang merupakan faktor risiko terjadinya ADHD } \\
\text { pada anak yaitu: penyakit somatik ibu saat hamil }\end{array}$ \\
Abdi, 2012) & $\begin{array}{l}\text { Deficit Hyperactivity } \\
\text { Disorder: A Case-Control }\end{array}$ & 166 kontrol & & (OR: 3.91, 95\%CI:1.5-9.9), gangguan kejiwaan \\
& Study & & (OR: $16.1,95 \%$ CI: 3.7-69.1), paparan alkohol dan \\
& & & $\begin{array}{l}\text { rokok selama kehamilan (OR: 4.1, 95\%CI: } 1.3-12.5) \\
\text { dan Riwayat persalinan dengan operasi sesar (OR: }\end{array}$ \\
& & & $3.0,95 \%$ CI: 1.9-4.7) \\
\hline
\end{tabular}

\section{Pembahasan}

Riwayat ibu merokok saat hamil diduga kuat merupakan faktor risiko ADHD pada anak, hal ini sejalan dengan penelitian yang dilakukan Biederman et al., (2017) dimana didapatkan hasil ada hubungan yang signifikan antara ibu merokok saat hamil terhadap kejadian ADHD pada anak yang dilahirkan, beberapa penelitian lain juga mendapatkan hasil yang serupa antara perilaku merokok ibu saat hamil dengan kejadian ADHD pada anak (Biederman et al., 2017; Noordermeer et al., 2017; Saadi et al., 2013; Schwenke et al., 2018). Berbagai kandungan bahan kimia yang terdapat dalam rokok diduga kuat dapat meningkatkan kejadian ADHD pada anak. Paparan asap rokok atau tembakau signifikan meningkatkan kejadian ADHD(Wang et al., 2019), kandungan polycyclic aromatic hydrocarbons (PAH) asap rokok diduga kuat menjadi penyebab ADHD pada anak (Perera et al., 2018). 
Bali Medika Jurnal.

Vol 8 No 1, 2021: 35-44

ISSN : 2615-7047

DOI: https://doi.org/10.36376/bmj.v8i1

Alkohol merupakan salah satu faktor yang diduga meningkatkan kejadian ADHD pada anak (Davison et al., 2010), gejala ADHD pada anak mengalami peningkatan pada orang tua pecandu alkohol (Beaver et al., 2012), menurut Amiri et al., (2012) ibu yang terpapar alkohol semasa hamil menjadi salah satu risiko ADHD pada anak dikemudian hari. Kejadian ADHD pada anak dikaitkan dengan multifaktorial dari ibu saat hamil, ibu hamil yang obesitas diduga kuat meningkatkan kejadian ADHD (Andersen et al., 2018).

Beberapa risiko saat anak baru lahir dikaitkan dengan kejadian ADHD pada anak dikemudian hari, riwayat kelahiran dengan berat badan lahir rendah diduga sangat berhubungan dengan kejadian ADHD, hal ini didukung oleh penelitian yang dilakukan Noordermeer et al., (2017) BBLR bertindak sebagai faktor risiko ADHD, selain BBLR Riwayat kelahiran prematur dan APGAR skor saat lahir rendah juga dikaitkan dengan kejadian ADHD, anak yang terlahir premature mempunyai risiko 1,5 kali lebih besar mengalami ADHD dimasa mendatang (Istiklaili et al., 2019), sedangkan skor APGAR rendah atau kurang dari 7 pada awal kelahiran meningkatkan risiko ADHD pada anak (Hanć et al., 2018; Schwenke et al., 2018). Riwayat proses persalinan dengan sectio caesaria meningkatkan risiko 3 kali lebih besar bila dibandingkan persalinan normal (Amiri et al., 2012).

Riwayat genetik merupakan risiko yang tidak bisa dipisakan dengan kejadian ADHD pada anak, orang tua atau keluarga yang mempunyai Riwayat kejadian ADHD mempunyai risiko lebih besar mempunyai anak-anak dengan ADHD. Risiko ADHD akan tinggi bila ada anggota keluarga mempunyai Riwayat ADHD atau ASD (Septier et al., 2019), orang tua yang mengalami ADHD cenderung memiliki keturunan ADHD (Adiputra, Sutarga, \& Pinatih, 2015). Genetik dan faktor lingkungan Bersama-sama meningkatkan kejadian ADHD (Tuvblad et al., 2009).

Selain dari faktor biologis ada beberapa faktor lain yang diduga berkaitan dengan kejadian ADHD pada anak, usia orang tua yang terlalu muda juga dikaitkan dengan kejadian ADHD, hal ini mungkin disebabkan karena kesiapan dari orang tua dalam melakukan tugas dan fungsinya masih kurang, menurut Chudal et al., (2015) ayah atau ibu yang berusia dibawah 20 tahun memiliki risiko 1,5kali lebih besar memiliki anak ADHD. Sosial ekonomi dan faktor lingkungan juga dikaitkan dengan kejadian ADHD, menurut Hegelund et al., (2019) orang tua dengan sosial ekonomi rendah memiliki risiko yang lebih tinggi mempunyai anak dengan ADHD, sosial ekonomi sangat berkaitan dengan kualitas hidup seseorang, semakin baik sosial ekonomi seseorang maka kualitas hidup seseorang akan lebih baik. Lingkungan juga memiliki andil yang sangat penting akan kejadian ADHD, semakin baik lingkungan tempat tinggal suatu keluarga maka semakin kecil kemungkinan memiliki anak ADHD, lingkungan dan genetik mempunyai pengaruh yang signifikan dengan kejadian ADHD (Lehti et al., 2016; Tuvblad et al., 2009)

\section{KESIMPULAN}

Faktor risiko yang meningkatkan kejadian ADHD: Paparan asap rokok, Ibu merokok dan mengkonsumsi alkohol saat hamil, Ibu hamil yang obesitas, Riwayat kelahiran dengan berat badan lahir rendah (BBLR) dan kelahiran Prematur, APGAR skor rendah saat lahir, genetik dan lingkungan, social ekonomi orang tua, 
usia orang tua dan Riwayat kelahiran sectio caesaria (SC). Mengacu pada hasil literatur review pada artikel ini, dimana ada beberapa faktor risiko yang bisa dirubah dan dicegah terkait perilaku kesehatan (ibu merokok saat hamil, terpapar asap rokok saat hamil, mengonsumsi alkohol dan obesitas), maka disarankan untuk petugas kesehatan memberikan pendidikan kesehatan kepada ibu hamil terkait perilaku-perilaku negatif yang akan meningkatkan risiko kejadian ADHD pada anak yang akan dilahirkan.

\section{DAFTAR PUSTAKA}

Abdel Hamed, N. A., Hammad, E. E. D. M., Salama, R. H., Yassa, H. A., \& Awaga, M. M. (2019). Secondhand smoke as a risk factor for attention deficit hyperactivity disorder in children. Inhalation Toxicology, 31(11-12), 420-427. https://doi.org/10.1080/08958378.2019.1705440

Adiputra, I. M. S., Sutarga, I. M., \& Pinatih, G. N. I. (2015). Faktor Risiko Attention Deficit Hyperactivity Disorder (ADHD) pada Anak di Denpasar. Public Health and Preventive Medicine Archive, 3(1), 35. https://doi.org/10.15562/phpma.v3i1.84

Adiputra, I. M. S., Trisnadewi, N. W., \& Parlin, G. A. K. U. (2018). GAMBARAN TINGKAT PENGETAHUAN KELUARGA TENTANG ADHD DI PAUD KECAMATAN DENPASAR UTARA. Bali Medika Jurnal, I. https://doi.org/https://doi.org/10.36376/bmj.v5i1.15

Amiri, S., Malek, A., Sadegfard, M., \& Abdi, S. (2012). Pregnancy-Related Maternal Risk Factors of Attention-Deficit Hyperactivity Disorder: A CaseControl Study. ISRN Pediatrics, 2012, 1-5. https://doi.org/10.5402/2012/458064

Andersen, C. H., Thomsen, P. H., Nohr, E. A., \& Lemcke, S. (2018). Maternal body mass index before pregnancy as a risk factor for ADHD and autism in children. European Child and Adolescent Psychiatry, 27(2), 139-148. https://doi.org/10.1007/s00787-017-1027-6

Beaver, K. M., Nedelec, J. L., Rowland, M. W., \& Schwartz, J. A. (2012). Genetic risks and ADHD symptomatology: Exploring the effects of parental antisocial behaviors in an adoption-based study. Child Psychiatry and Human Development, 43(2), 293-305. https://doi.org/10.1007/s10578-0110263-0

Biederman, J., Martelon, M. K., Woodworth, K. Y., Spencer, T. J., \& Faraone, S. V. (2017). Is Maternal Smoking During Pregnancy a Risk Factor for Cigarette Smoking in Offspring? A Longitudinal Controlled Study of ADHD Children Grown Up. Journal of Attention Disorders, 21(12), 975-985. https://doi.org/10.1177/1087054714557357

Chen, M. H., Su, T. P., Chen, Y. S., Hsu, J. W., Huang, K. L., Chang, W. H., ... 
Bai, Y. M. (2014). Is atopy in early childhood a risk factor for ADHD and ASD? A longitudinal study. Journal of Psychosomatic Research, 77(4), 316321. https://doi.org/10.1016/j.jpsychores.2014.06.006

Chudal, R., Joelsson, P., Gyllenberg, D., Lehti, V., Leivonen, S., Hinkka-YliSalomäki, S., ... Sourander, A. (2015). Parental age and the risk of attentiondeficit/hyperactivity disorder: A nationwide, population-based cohort study. Journal of the American Academy of Child and Adolescent Psychiatry, 54(6), 487-494.e1. https://doi.org/10.1016/j.jaac.2015.03.013

Davison, G. C., Neale, J. M., \& Kring, A. M. (2010). Psikologi Abnormal (10th ed.). Jakarta: Raja Grafindo Persada.

Hanć, T., Szwed, A., Słopień, A., Wolańczyk, T., Dmitrzak-Węglarz, M., \& Ratajczak, J. (2018). Perinatal Risk Factors and ADHD in Children and Adolescents: A Hierarchical Structure of Disorder Predictors. Journal of Attention Disorders, 22(9), 855-863.

https://doi.org/10.1177/1087054716643389

Hegelund, E. R., Flensborg-Madsen, T., Vassard, D., Niclasen, J., \& Mortensen, E. L. (2019). Parental socioeconomic position and risk of ADHD in offspring: a cohort study of 9648 individuals in Denmark 1976-2013. European Child and Adolescent Psychiatry, 28(5), 685-693. https://doi.org/10.1007/s00787-018-1235-8

Istiklaili, F., Suwandono, A., Suhartono, S., Widyorini, E., \& Saputro, D. (2019). Risk factors affecting attention deficit hyperactivity disorder among early childhood in the agricultural area in Indonesia. Indian Journal of Public Health Research and Development, 10(1), 417-421. https://doi.org/10.5958/0976-5506.2019.00083.4

Lehti, V., Chudal, R., Suominen, A., Gissler, M., \& Sourander, A. (2016). Association between immigrant background and ADHD: a nationwide population-based case-control study. Journal of Child Psychology and Psychiatry and Allied Disciplines, 57(8), 967-975. https://doi.org/10.1111/jcpp.12570

Muninggar, G. T. (2011). Hubungan GPPH (Gangguan Pemusatan Perhatian Hiperaktifitas) Dengan Prestasi Belajar Siswa Di SDN Perumnas Bumi Kelapa Dua Tanggerang. Jakarta.

Noordermeer, S. D. S., Luman, M., Weeda, W. D., Buitelaar, J. K., Richards, J. S., Hartman, C. A., ... Oosterlaan, J. (2017). Risk factors for comorbid oppositional defiant disorder in attention-deficit/hyperactivity disorder. European Child and Adolescent Psychiatry, 26(10), 1155-1164. https://doi.org/10.1007/s00787-017-0972-4

Perera, F. P., Wheelock, K., Wang, Y., Tang, D., Margolis, A. E., Badia, G., ... 
Herbstman, J. B. (2018). Combined effects of prenatal exposure to polycyclic aromatic hydrocarbons and material hardship on child ADHD behavior problems. Environmental Research, 160(September), 506-513. https://doi.org/10.1016/j.envres.2017.09.002

Saadi, H. R., Shamsuddin, K., Sutan, R., \& Alshaham, S. A. (2013). Sociomaternal risk factors of ADHD among Iraqi children: A case-control study. Open Journal of Preventive Medicine, 03(02), 251-257. https://doi.org/10.4236/ojpm.2013.32034

Schwenke, E., Fasching, P. A., Faschingbauer, F., Pretscher, J., Kehl, S., Peretz, R., ... Schneider, M. (2018). Predicting attention deficit hyperactivity disorder using pregnancy and birth characteristics. Archives of Gynecology and Obstetrics, 298(5), 889-895. https://doi.org/10.1007/s00404-018-4888-0

Septier, M., Peyre, H., Amsellem, F., Beggiato, A., Maruani, A., Poumeyreau, M., ... Delorme, R. (2019). Increased risk of ADHD in families with ASD. European Child and Adolescent Psychiatry, 28(2), 281-288. https://doi.org/10.1007/s00787-018-1206-0

Tuvblad, C., Zheng, M., Raine, A., \& Baker, L. A. (2009). A common genetic factor explains the covariation among ADHD ODD and CD symptoms in 910 year old boys and girls. Journal of Abnormal Child Psychology, 37(2), 153-167. https://doi.org/10.1007/s10802-008-9278-9

Wang, Y., Hu, D., Chen, W., Xue, H., \& Du, Y. (2019). Prenatal Tobacco Exposure Modulated the Association of Genetic variants with Diagnosed ADHD and its symptom domain in children: A Community Based CaseControl Study. Scientific Reports, 9(1), 1-9. https://doi.org/10.1038/s41598019-40850-w 